\title{
Ki-67 cell proliferation in familial and in esporadic unilateral retinoblastoma: case report
}

\author{
Avaliaçãoda proliferaçãocelularcom marcador Ki-67 em pacientescom \\ retinoblastoma unilateral esporádico e familiar: rela todecaso
}

\author{
Maria Teresa Brizzi Chizzotti Bonanomi ${ }^{1}$ \\ Fernando Betty Cresta ${ }^{2}$ \\ Clayton César Tokunag'a ${ }^{3}$ \\ Ruth Miyuki Santo ${ }^{4}$ \\ Otacilio de Oliveira Maia ${ }^{5}$ \\ Walter Yukihiko Takahashi ${ }^{6}$
}

\begin{tabular}{l} 
ABSTRACT \\
\hline Purpose: Ki-67 is a nuclear protein that is expressed at all phases of the cell \\
cycle except the resting phase. This study is a clinicopathologic observa- \\
tional case report that aims to report on the cell proliferation rates, as \\
measured by the Ki-67 antigen, in two enucleated retinoblastoma eyes. \\
Methods: One unilateral familial (mother with unilateral disease-patient 1 ) \\
and one unilateral sporadic retinoblastoma (patient 2 ) patients were sub- \\
mitted to enucleation without previous treatment. The tumor cell prolifera- \\
tion rate was assessed by the Ki-67 antigen labeling index (stained cells / 100 \\
cells) in five different fields of the tumor. Results: Patient 1 was 23 months \\
old and the tumor was exophytic with associated neovascularization of the \\
iris; patient 2 was 6 years old and the tumor was endophytic with coarse \\
vitreous seeds. Both enucleated eyes presented optic nerve with free \\
surgicalmargins. Positive Ki-67cellindexinpatient 1 varied from 75 to 90 (MD \\
\pm SD: $79.5 \pm 6.61$ ) and in patient 2 from 38 to 60 (MD \pm SD: $46.6 \pm 8.2$ ). \\
Conclusions: The familial retinoblastoma, besides the earlier age presen- \\
tation, showed $45.8 \%$ more Ki-67 positive cells than the same stage \\
sporadic one. This proliferation rate may explain the earlier presentation \\
age of the tumor in the inherited disease.
\end{tabular}

Keywords: Retinal neoplasms; Retinoblastoma/congenital; Cell proliferation; DNA fragmentation; DNA, neoplasm/analysis; Ki-67 antigen/analysis

Clínicas Universidade de São Paulo - Brazil.

${ }^{1}$ Assistant Professor of the Retina Service. Hospital das Clínicas - Universidade de São Paulo - USP - São Paulo (SP) - Brasil

${ }^{2}$ Assistant Professor of the Retina Service. Hospital das Clínicas da USP - São Paulo (SP) - Brasil.

${ }^{3}$ Ophthalmology Resident of the Retina Service. Hospital das Clínicas da USP - São Paulo (SP) - Brasil

${ }^{4}$ Assistant Professor of the Ophthalmic Pathology Service. Hospital das Clínicas da USP - São Paulo (SP) - Brasil.

${ }^{5}$ Physician of the Retina and Vitreous Service Hospital das Clínicas da USP - São Paulo (SP) - Brasil.

${ }^{6}$ Head of the Retina and Vitreous Service. Hospital das Clinicas da USP - São Paulo (SP) - Brasil.

Corresponding author: Maria Teresa B. C. Bonanomi HCFMUSP Oftalmologia. Av Enéas de Carvalho Aguiar, 255 - São Paulo (SP) - Brasil - CEP 05403-000 E-mail: mtbonanomi@uol.com.br

Recebido para publicação em 01.05.2006

Aprovação em 19.10.2006

Nota Editorial: Depois de concluída a análise do artigo sob sigilo editorial e com a anuência da Dra. Clélia Maria Erwenne sobre a divulgação de seu nome como revisor, agradecemos sua participação neste processo.

Proprietary interest: none

\section{INTRODUCTION}

Retinoblastoma is the most common intraocular malignancy in child$\operatorname{hood}^{(1)}$. This highly malignant neoplasm is known to emerge from the nuclear layers of the retina following two genetic bouts that suppress both alleles of the RB1 gene ${ }^{(2)}$. The diagnosis of the site of mutation, only in the tumor or, in the tumor and elsewhere in the body is the straight way to separate sporadic from familial disease. Since in the detection of the mutation through genetic mapping or through the indirect method of the esterase D activity ${ }^{(3)}$ cell culture is involved and is not generally available or cost effective, indirect clinical clues are used to assume the double germ mutation in a retinoblastoma case. The clinical indicators for inherited disease are early appearance age, bilateral disease and positive family history. Quantitative immunohistochemical analysis of cell proliferation, apoptosis and angiogenesis, have been reported recently in oncology ${ }^{(4-10)}$, and in other areas in ophthalmolo$\mathrm{gy}^{(11)}$. For retinoblastoma it was shown that the proliferation index, instead of

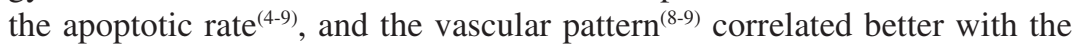
prognosis. The cell proliferation rates as measured by the Ki-67 antigen in two enucleated unilateral retinoblastoma eyes are reported.
\end{abstract}




\section{METHODS}

One unilateral familial (mother with unilateral disease patient 1) and one unilateral sporadic (patient 2) retinoblastoma patients were submitted to enucleation only. For immunohistochemical evaluation of Ki-67 the tissue sections were deparaffinized and hydrated using xylene and graded alcohol. Endogenous peroxidase was quenched with $3.0 \%$ hydrogen peroxidase in methanol for 10 minutes. Following phosphatebuffered saline (PBS) rinses, sections were immersed in citrate buffer (10 mM citric monohydrate, adjusted to $\mathrm{pH} 6.0$ ) and heated in a microwave over at boiling point for 20 minutes. Then, the microwave-irradiated sections were cooled to room temperature and washed with PBS. They were then incubated in protein blockage solution (Zymed Laboratories, San Francisco, CA, USA) for 10 minutes. Sections were incubated with primary antibodies; mouse anti-human monoclonal antibody (Neomarkers, Fremont, CA, USA) diluted in 1:100 PBS for Ki-67 immunostaining. After PBS rinse, sections were treated with biotinylated second antibody (Zymed) for 10 minutes and enzyme conjugate (HRP-streptavidin, Zymed) for $10 \mathrm{minu}$ tes at room temperature ${ }^{(12)}$. Once Ki-67 positive cell density may not be uniform inside the same tumor ${ }^{(4)}$, the tumor cell proliferation rate was assessed by the Ki-67 stained cells, in 100 cells, of five different fields of the tumor. The mean, called proliferation index $(\mathrm{P})$ and pattern deviation (Mean $\pm \mathrm{SD})$, as well as the median of positive nuclear stained cells in the 5 fields, was calculated and the differences between the two patients are shown in percentage.

\section{RESULTS}

Patient 1 was a 23-month-old boy with the right eye affected. The enucleation was chosen as the only treatment based on the presence of extensive iris neovascularization. The anatomopathologic analysis showed a large, mostly exophytic tumor (17 $\mathrm{mm}$ at the base), $60 \%$ necrotic with sparse calcification and Hommer-Wright rosettes. The tumor invaded the choriocapillaris but spared the choroids themselves; the optic nerve was invaded up to the lamina cribosa with free surgical margins. The $\mathrm{P}$ value in this patient varied from 75 to $90(79.5 \pm$ 6.61), median: 84 (Figure 1 A, B). Patient 2 was a 6-year-old girl with the right eye affected. The enucleation was chosen as the only treatment because the retina was totally detached and there were coarse vitreous and subretinal tumor seeds. The anatomicopathologic analysis showed a large endophytic tumor (12 $\mathrm{mm}$ at the base); the tumor cells were highly undifferentiated without any typical rosette, necrosis and sparse calcification areas. The choroids underneath the nasal part of the tumor showed mass infiltration up to the lamina fusca. The optic nerve was infiltrated up to $1 \mathrm{~mm}$ posterior to the lamina cribosa but the surgical margins were free from tumor. The $\mathrm{P}$ value in this patient varied from 38 to $60(46.6 \pm 8.2)$ (Figure $1 \mathrm{C}, \mathrm{D})$, median: 45 . The inherited retinoblastoma, besides its earlier age presentation, showed $45.8 \%$ more Ki-67 positive cells than the sporadic one, in the same stage.

\section{DISCUSSION}

The balance between proliferation and cell death is the major determinant of tumor growth. For retinoblastoma it was shown that the proliferation rate, instead of the apoptotic rate $^{(4-9)}$, and the vascular pattern ${ }^{(8-9)}$ correlated better with the prognosis. Antigen Ki-67 reacts with a DNA associated antigen in the nuclei at all phases of the cell cycle except the resting phase and it is considered a gold standard for cell proliferation in many tissues ${ }^{(8,10-11)}$ with the advantage related to its availability and technical easiness. Recent reports showed a positive correlation between $\mathrm{P}$ and clinical stage ${ }^{(5-6)}$. In a series of 33 retinoblatomas ( 5 bilateral) the reported mean $\mathrm{P}$ value was $21 \pm 2.1$ and, if the proliferative index was in excess of 40 , it was clearly associated with unfavorable diagnosis ${ }^{(5)}$. In another report of 62 unilateral and 24 bilateral cases of nonfamilial retinoblastoma, a highly significant correlation between stage and $\mathrm{P}$ value for unilateral disease was shown; for the advanced stages ( 3 and up), $\mathrm{P}$ was $81.25 \pm 6.78$ and for stages 1 and $2 \mathrm{P}$ was $69.50 \pm 9.45(\mathrm{p}=0.001)$. Among children with bilateral disease, however, $\mathrm{P}$ was not significantly higher for advanced clinical stage than for less advanced disease. It was suggested that unregulated cell growth contributes to a more aggressive disease phenotype for tumors without a germinal loss of $\mathrm{pRb}^{(7)}$. We demonstrated a higher proliferation index in the inherited case (mean: 79.5, median 84) than in the sporadic one (mean: 46.6, median 45) in the same tumor stage. These two high $\mathrm{P}$ indices are in accordance with the literature for advanced stage disease but our patients are free of systemic disease in the follow-up period of 2 years and therefore considered cured. Though it was shown that high prolifera-
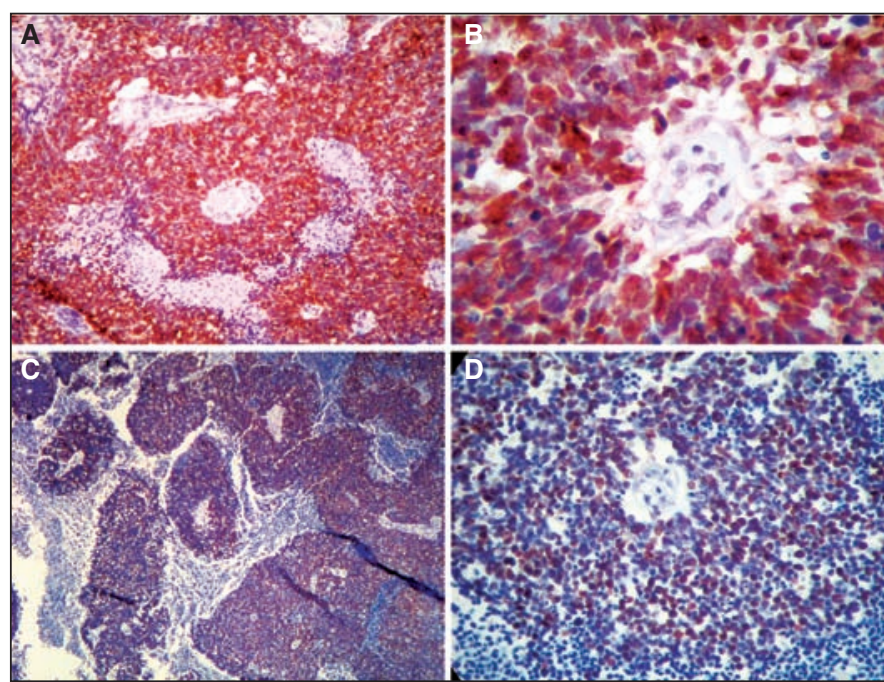

Figure - Microscope fields showing Ki-67 labeling in a overview of the tumor (100xs) and with amplified (250xs) respectively for patient 1: $A, B(M D \pm S D: 79.5 \pm 6.61)$, and for patient $2: C, D(M D \pm S D: 46.6 \pm 8.2)$ 
tion rate is correlated with a poor prognosis ${ }^{(5,8)}$, a well-performed enucleation with free surgical margins seems to play an important role in the prevention of a disseminated disease. The inherited retinoblastoma, besides its earlier age presentation, showed $45.8 \%$ more Ki-67 positive cells than the sporadic one, in the same stage. The difference in the $\mathrm{P}$ index in our patients could be explained by the presence of a different amount of $\mathrm{Rb}$ protein $(\mathrm{pRb})$ in the tumor cell nuclei of the familial and the sporadic retinoblatoma. Although it was unexpected, different amount of this suppression factor $(\mathrm{pRb})$ was found in retinoblatoma and, such as in other malignancies ${ }^{(11)}$, its expression was shown to relate inversely with the $\mathrm{P}$ index ${ }^{(7)}$. The high $\mathrm{P}$ in patient 1, associated with other factors, may have been responsible for the earlier appearance of the tumor in this inherited disease. If future prospective investigations with antigen Ki-67 labeling confirm the present study, and an index for familial and sporadic cases is settled, Ki-67 labeling could be an additional tool in retinoblastoma genetic counseling.

\section{CONCLUSION}

The inherited retinoblastoma, besides its earlier age presentation, showed $45.8 \%$ more Ki-67 positive cells than the sporadic one, in the same stage.

\section{RESUMO}

Objetivo: O Ki-67 é antígeno nuclear que se expressa em todas as fases do ciclo celular, exceto no período de repouso. Este é um estudo de casos com correlação clínico-patológica que visa avaliar a taxa de proliferação celular, medida pelo antígeno Ki-67, em 2 olhos enucleados com retinoblastoma. Métodos: Um paciente com retinoblastoma unilateral familiar (mãe com doença unilateral - paciente 1) e outro com retinoblastoma unilateral esporádico (paciente 2) foram submetidos à enucleação ocular sem outro tratamento prévio. A taxa de proliferação celular foi avaliada segundo índice obtido pela contagem de células marcadas com Ki-67, em 5 campos sob microscópia óptica (células marcadas/100 células). Resultados: O paciente 1, com 23 meses de idade, apresentou tumor exofítico com neovascularização de íris associada; o paciente 2 , de 6 anos, apresentou tumor de crescimento endofítico, com sementes vítreas importantes. Ambos os olhos enucleados apresentaram margens cirúrgicas do nervo óptico livres de neopla- sia. O índice de células positivas no paciente 1 variou de 75 a 90 (Média \pm DP: 79,5 $\pm 6,61$ ), e no paciente 2, de 38 a 60 (Média \pm DP: $46,6 \pm 8,2)$. O retinoblastoma familiar, além de sua manifestação em idade mais precoce, apresentou 45,8\% mais células positivas que o retinoblastoma esporádico com o mesmo estadiamento. Conclusão: O retinoblastoma familiar, além de surgimento mais precoce, apresentou 45,8\% mais células em proliferação que o retinoblastoma esporádico em mesmo estádio. Essa taxa de proliferação pode explicar a menor idade de aparecimento do tumor nos casos de doença herdada.

Descritores: Neoplasias da retina; Retinoblastoma/congênito; Proliferação de células; Fragmentação de DNA; DNA de neoplasias/análise; Antígenos Ki-67/análise

\section{REFERENCES}

1. Shields JÁ. Retinoblastoma. In: Shields JÁ. editor. Diagnosis and management of intraocular tumors. St. Louis: CV. Mosby Company; 1983. p.437-96.

2. Knudson AG JR. Mutation and cancer: Statistical study of retinoblastoma. Proc Nat Acad Sci: USA. 1971;68(4):820-3

3. Cowell JK, Hungerford J, Rutland P, Jay M. Genetic and cytogenetic analysis of patients showing reduced esterase-D levels and mental retardation from a survey of 500 individuals with retinoblastoma. Ophthalmic Paediatr Genet. $1989 ; 10(2): 117-27$

4. Coupland SE, Bechrakis N, Schüler A, Anagnostopoulos I, Hummel M, Bornfeld N, Stein H. Expression patterns of cyclin D1 and related proteins regulating G1-S phase transition in uveal melanoma and retinoblastoma. Brit J Ophthalmol. 1998;82(8):961-70.

5. Kim CJ, Chi JG, Choi HS, Shin HY, Ahn HS, Yoo YS, Chang KY. Proliferation not apoptosis as a prognostic indicator in retinoblastoma. Virchows Arch. 1999;434(4):301-5.

6. Schwimer CJ, Prayson RA. Clinicopathologic study of retinoblastoma including MIB-1, p35 and CD99 Immunohistochemistry. Ann Diagn Pathol. 2001;5(3):148-54.

7. Orjuela M, Orlow I, Dudas M, Ponce-Castañeda MV, Ridaura C, Leal C, Salazar A, Abramson D, Gerald W, Condon-Cardo C. Alterations of cell cycle regulators affecting the $\mathrm{Rb}$ pathway in nonfamilial retinobaltoma. Human Pathol. 2001;32(5):537-44.

8. Kerimogglu H, Kiratli H, Dinçtürk AA, Söylemezoglu F, Bilgiç S. Quantitative analysis of proliferation, apoptosis an angiogenesis in retinoblastoma and their association with the clinicopathologic parameters. Jpn J Ophthalmol. 2003;47(6):565-71.

9. Marback EF, Arias VE, Paranhos A Jr, Soares FA, Murphree AL, Erwenne $\mathrm{CM}$. Tumor angiogenesis as a prognostic factor for disease dissemination in retinoblastoma. Br J Ophthalmol. 2003;87(10):1224-8.

10. Schwimer CJ, Prayson RA. Clinicopathologic study of retinoblastoma including MIB-1, p53 and CD99 immunohistochemistry. Ann Diagn Pathol. 2001;5(3):148-54.

11. Cresta FB. Avaliação da cinética do epitélio corneano de coelhas com marcadores de proliferação celular [tese]. São Paulo: Universidade de São Paulo; 2002.

12. Nakamura M, Konishi N, Tsunoda S, Hiasa Y, Tsuzuki T, Inui T, Sakaki T. Retinoblastoma protein expression and MIB-1 correlate with survival of patients with malignant astrocitoma. Cancer. 1997;80(2):242-9.

\section{Nos artigos enviados para publicação, o nome dos autores} e suas afiliações devem estar completos. Isso facilitará a indexação e os links com as bases de dados e o CV Lates. 